\title{
DIASPORAS MOBILIZĒŠANA: IESPĒJAS SABIEDRĪBAS ATJAUNOŠANAI LATVIJĀ
}

\author{
Aija Lulle \\ LU G̦ZZF, e-pasts: aija.lulle@lu.Iv
}

\begin{abstract}
Anotācija. Rakstā analizēta geogrāfiskā literatūra par diasporas mobilizēšanas iespējām pasaulē. To izmantojot, norādīti diasporas mobilizēšanas raksturīgākie veidi un analizēts, kā tie īstenoti Latvijā. Rakstā secināts, ka Latvijā ir samērā plaša diasporas mobilizēšanas prakse, gan individuālā, gan arī valstiskā līmenī. Lai veidotu iespējami noturīgākas saiknes ar diasporu, nākotnē vēlams veidot ilgtspējīgas politikas iniciatīvas, kam pamatā ir savstarpējā - valsts un diasporas - uzticība, kā arī veicināt kopīgas attīstības iniciatīvas regionālā līmenī. Nozīmīgi ir arī attīstīt politikas, kas vêrstas uz plašākām grupām - kvalificētiem speciālistiem, vidēja un vecāka gadagājuma cilvēkiem, kā arī veidot sabiedrībā izpratni par diasporas nozīmi Latvijas sabiedrības atjaunošanai.
\end{abstract}

Atslēgas vārdi: Latvija, diasporas mobilizēěana, sabiedrības atjaunošana.

\section{Ievads}

Pēc Ārlietu ministrijas (ĀM 2013) aplēsēm vairāk nekā 300 tūkstoši Latvijai piederīgo dzīvo ārpus Latvijas teritorijas, ietverot arī otro un trešo paaudzi - tos, kuru vecāki un vecvecāki pameta Latviju, galvenokārt, dodoties bēg̣̣u gaitās vai arī nonākot izsūtījumā.

Diasporas politikas mobilizēšana, izveidojot speciālus vēstnieku un departametu vadītāju posteņus, kas atbildīgi par diasporas lietām, ir aizvien vairāk raksturīga valstīs, kas piedzīvojušas daudzskaitlīgu emigrāciju. Cilvēki arī ārpus dzimtenes turpina uzturēt emocionālu pieķeršanos valstij, sūta naudu tuviniekiem, apciemo radus un dą̣a cenšas uzturēt savas tautības indentitāti pat tad, ja vairs neplāno atgriezties dzimtenē (Cohen 2008). Mobilizējot diasporu - gan politiski, proti, no augšas uz apakšu, gan, veicinot pašorganizēšanos diasporas kopienās, tātad no apakšas uz augšu, diaspora veidojas kā ekonomiski, politiski un kulturāli svarīga, neatņemama Latvijas tautas daļa. Turpmāk tekstā īsumā aprakstīts analizētais materiāls, galvenās atziņas un secinājumi par diasporas mobilizēšanu Latvijā.

\section{Materiāls un metodes}

Analīzei izmantota literatūras un dokumentu analīze. Pirmkārt, īsi aplūkoju geogrāfisku pētījumu literatūrā rodamās diasporas mobilizēšanas izpausmes. Otrkārt, skaidroju, kādas diasporas mobilizēšanas formas tiek izmantotas Latvijā. Visbeidzot, raksturoju, kādas iniciatīvas vēl tikai veidojas un būtu vēlams attīstīt sabiedrības atjaunošanai Latvijā.

\section{Interpretācija: diasporas mobilizēšanas iespējas}

Diasporu parasti veido cilvēki, kuri ārzemēs plāno palikt ilgi, visbiežāk -visu mūžu. Tomēr, arī neatgriežoties dzimtenē, viņi vēlas un var sniegt ieguldījumu izcelsmes valstī. Britu geogrāfs Maiks Koljers (Collyer 2013: 7) uzsver, ka paša termina "diaspora" lietošana attiecībā uz visiem ārpus valsts teritorijas dzīvojošajiem pilsoṇiem vai valstspiederīgajiem, rada pozitīiāku attieksmi, salīdzinot ar terminu "emigranti." 
Diasporas locekḷi ir vairāk ieinteresēti ieguldīt izcelsmes valstī un turpināt uzturēt saiknes ar to.

Literatūrā rodamas sekojošas galvenās diasporas mobilizēšanas formas:

- Vispārējas politikas veidošana diasporas mobilizēšanai, lai saglabātu saiknes un veicinātu zināšanu apmaiņu, kā arī diasporas ekonomisko resursu piesaisti izcelsmes valstij.

- Kopīgu attīstības (co-development - angliski) stratēǵiju, kas ietver partnerus no izcelsmes valsts vai reǵiona, kā arī pašreizējās mītnes valsts partnerus un diasporas organizācijas.

- Dzimtās pilsētas kopienas (hometown associations - angliski), kas parasti ir brīvprātīgi veidotas, diasporas locekḷu iniciatīvas palīdzēt dzimtajai pilsētai vai novadam, piemēram, atjaunojot skolas, ceḷot sporta kompleksus utt., atkarībā no vietējās kopienas vajadzībām (plašāk skatīt, piemēram, King, Lulle 2016).

Šādā veidā diasporas locekḷi īsteno noteikta tipa ieguldījumus, no kuriem būtiskākie ir šādi:

- uzṇēmējdarbības aktivitātes izcelsmes valstī kopā ar vietējiem iedzīvotājiem vai tiem, kuri atgriezušies no emigrācijas,

- ieguldījumi biznesa attīstībā, tai skaitā, arī valsts vadītos projektos,

- labdarība - ziedojumu un palīdzības fondu veidošana,

- diasporas locekḷu brīvprātīgais darbs, īpaši raksturīgs jaunatnei vai jau pensionētiem diasporas locekḷiem,

- mācības un mentoringa darbība,

- kopīga attīstība (co-development) - centieni novirzīt naudas sūtījumus tā, lai tie kalpotu ne tikai mājsaimiecību patēriņam, bet arī plašākiem kopienu projektiem, savukārt pretī saņemtu izcelsmes valsts politisku un iespēju robežās, arī ekonomisku atbalstu projektu ilgtspējai, pašiem diasporas locekḷiem nepārceḷoties uz dzīvi izcelsmes valsī. Šajā tipā parasti veidojas diasporas līderi - biznesa un politiskie (de Haas 2006; Sørensen 2007; Brinkerhoff 2008; Newland, Tanaka 2010).

Latvijā atškirīīgās pakāpēs ir rodamas dažādas šo tipu darbības. Diasporas locekḷi dibina uzņēmumus, piemēram, tūrisma, mazumtirdzniecības, transporta pakalpojumus. Lielākas organizācijas, piemēram, Pasaules Brīvo Latviešu apvienība (PBLA) piedalās un iniciē nozīmīgus projektus, piemēram, par tālmācības īstenošanu, gan organizācijas, gan indivīdu grupas, sāk veidot arī labdarības pasākumus, piemēram, vācot līdzekḷus bērnu namiem, aprūpes centriem.

Īpaši jāuzsver diasporas mobilizēšana (un pašorganizēšanās) mācību, metoringa un ekonomiskās attīstības veicināšanā. Visnozīmīgākais pasākums, kas jau ir noticis divas reizes, ir Pasaules latviešu ekonomikas un inovāciju forums (PLEIF 2015). Līdzīgi forumi diasporās notiek arī citās valstīs, piemēram, kaimiṇvalstī Lietuvā (Lithuanian Leaders 2016; Lithuanian Economic Forum 2016). Mentoringa mobilizēšanā nozīmīgākais piemērs ir prakses un darba vietu veidošana diasporas jauniešiem, Valsts Kanceleja (2015). L̄̄ì̄̄gas aktivitātes ir arī citviet Eiropā, piemēram, Lietuvā un Rumānijā (Kurk Lietuvai 2014; Aspen Institute Romania n.d.). Jau gadiem ilgi diaspora 
aktīvi atbalsta studentus un pētniekus, piedāvājot stipendijas un apmaiṇas braucienu finansēšanu, galvenokārt ASV.

Visbeidzot, lai arī Latvijā vēl nav iesakņojušās liela mēroga un ieguldījumu dzimtās pilsētas un novada aktivitātes, tomēr veidojas arī regionāla līmeņa diasporas mobilizēšana. Īpaši jāuzsver Cēsu pilsētas aktivitātes, izveidojot diasporas mākslas muzeju, organizējot konferences un pašvaldības darbinieku vizītes valstīs, kurās pašlaik mīt bijušie cēsinieki (piemēram, Īrijā un Lielbritānijā). Nozīmīga platforma ir jaunie mediji: piemēram, Preiḷu novads aktīvi izmanto Facebook platformu, publicējot darba sludinājumus un labās atgriešanās pieredzes stāstus grupā "Es atgriežos Preiḷos".

\section{Secinājumi}

Varam secināt, ka Latvijā pastāv samērā plašas diasporas mobilizēšanas iespējas. Starp tām nozīmīgākās ir naudas sūtījumi, kas parasti gan ir vairāk individuālā un gimeņu līmen̄i, diasporas mobilizēšana plaša mēroga, uz ekonomiku un inovācijām vērstiem pasākumiem, diasporas mobilizēšana noteiktās grupās - īpaši, jauniešu un vecāku, kuriem ir mazi bērni, grupās, mobilizēšana mediju telpā, kā arī reǵionāla līmeṇa diasporas mobilizēšana.

Diasporas mobilizēšana un iesaiste sabiedrības atjaunošanā nav viegls process. Tam ir daudz barjeru, tai skaitā, politiskas gribas trūkums pastāvīgi atbalstīt un nodrošināt finansējumu aktivitātēm, kas vēl tikai veidojas. Arī sabiedrībā ne vienmēr ir atbalsts un izpratne par to, cik daudz diaspora var sniegt Latvijas attīstībai. Tādēḷ ir jāturpina darbs ar sabiedrību, popularizējot diasporas sniegto atbalstu starptautiskā, nacionālā un reǵionālā līmenī.

\section{Pateicība}

Raksts izstrādāts ar Valsts pētījumu programmas pētnieciskā projekta Nr. 5.2.4. „Sabiedrības atjaunošana, samazinot depopulācijas riskus, veicinot tautas ataudzi un saiknes ar diasporu" atbalstu.

\section{Atsauces}

Aspen Institute Romania (n.d.) Aspen Institute Romania, organisation. Retrieved http://www.aspeninstitute.ro/ [aplūkots 22.02.2016]

$\bar{A} M$ (2013). Par Ārlietu ministrijas sadarbību ar Latvijas diasporu 2013.-2015. Informatīvs ziņojums.

Brinkerhoff, J.M. (ed.) (2008). .Diasporas and Development: Exploring the Potential. Boulder, CO: Lynne Riener.

Cohen, R. (2008). Global Diasporas: An Introduction. London: Routledge.

Collyer, M. (ed.) (2013). Emigration Nations: Policies and Ideologies of Emigrant Engagement. Basingstoke: Palgrave Macmillan.

de Haas, H. (2006). Engaging Diasporas: How Governments and Development Agencies can Support Diaspora Involvement in the Development of Origin Countries. Oxford: University of Oxford, International Migration Institute and Oxfam Novib. 
King, R. and Lulle, A. (2016). Facing Realities and Maximising Opportunities. A Policy Review. Brussels: Directorate General for Research and Innovation.

Kurk Lietuvai (2014). A placement programme for Lithuanian graduates from foreign universities. Pieejams: www.kurklt.lt/en (22.02.2016)

Lithuanian Economic Forum (2016) Lithuanian Economic Forum, Facebook group. Pieejams: http://www.plef.lt/ (22.02.2016)

Lithuanian Leaders (2016) Projects 'Lithuanian Leaders' and Global Lithuanian Leaders. Pieejams: http://www.lithuanianleaders.org/projects/ (22.02.2016)

Newland, K. and Tanaka, H. (2010). Mobilizing Diaspora Entrepreneurship for Development. Washington DC: Migration Policy Institute.

PLEIF (2015). Pasaules latviešu ekonomikas un inovāciju forums. Pieejams: www.ieguldilatvija.lv (22.02.2016)

Sørensen, N.N. (ed.) (2007). Living Across Worlds: Diaspora, Development Transnational Engagement. Geneva: International Organization for Migration.

Valsts Kanceleja (2015). Izsludinās pieteikšanos jauniešu reemigrācijas programmai "Darbs valsts pārvaldē" Pieejams: http://m.lvportals.lv/visi/preses-relizes?id=274928 (22.02.2016)

\section{Summary}

In this article, geographic literature on global diaspora mobilisation is analyzed. Based on this concise analysis, further analyzed are which practices are specifically implemented in Latvia. It can be concluded that there are abundance of diaspora mobilisation initiatives - on individual, as well as state and political levels. However, in order to develop stable and long term ties with diaspora, these initiatives should be based on mutual trust between the state and members of the diaspora. Additionally, it is important to develop more regional-level initiatives in future. More inclusive diaspora mobilisation for specific groups such as qualified workers, middle age and ageing people are needed. Moreover, raising awareness among the population of Latvia of the positive role of diaspora in Latvian societal renewal should be continuously provided alongside other diaspora initiatives. 